\title{
Improvement of informational technologies in ecology
}

\author{
Elmira Baimukhanbetova ${ }^{1^{*}}$, Darkhan Onaltayev ${ }^{1}$, Gulzhan Daumova ${ }^{2}$, Bakytzhan \\ Amralinova $^{2}$, Azamat Amangeldiyev ${ }^{1}$ \\ ${ }^{1}$ al-Farabi Kazakh National University, 71 al-Farabi Ave., 050040 Almaty, Republic of Kazakhstan, \\ ${ }^{2}$ Serikbayev East-Kazakhstan State University, Oskemen, Kazakhstan
}

\begin{abstract}
A powerful force in the development of modern society is the intensive global spread of information and communication technologies that help to collect, store, analyze and distribute information.Today, there is a clear need for a broadapplications of computer technologies in various fields human activities, and in particular in the protection of the environment. The most important areas are geographic information systems and associated modeling of natural resources, technological processes, as well as data preparation, processing and analyze systems. Currently, the rapid development of computer technology, the introduction of modern computer technologies opens up wide opportunities to achieve a qualitative leap in the level of efficiency of information and control systems in aerospace engineering, manufacturing, transport, economy, ecology, medicine and other areas based on the use of artificial intelligence principles, methods of self-organization and adaptation to changing conditions and goals of functioning, characteristics of the system and the external environment, uncontrolled environment.
\end{abstract}

\section{Introduction}

Modern information technologies have been widely implemented in various areas of human activity, and in particular in environmental protection. Currently, research on environmental protection is conducted in all areas of science and technology by various organizations and at various levels. The problem of the relationship between human society and the environment has become acute. Over the past decades, the risk of major environmental disasters caused by humans and resulting from the protective reaction of nature has increased. Human activity is constantly associated with the accumulation of information about the environment, its selection and storage. Information systems, whose main purpose is to provide information to the user, that is, to provide him with the necessary information on a specific problem or issue, help a person to solve problems faster and better. The same data can be used for different tasks and vice versa. Any information system is designed to solve a certain class of problems and includes both data storage and tools for implementing various procedures. The General purpose of information support for environmental research is to study information flows and prepare materials for decision-making at all levels of management in the implementation of environmental research, justification of individual research projects.

An integral attribute of modern technological production is the requirement to control the impact on the environment, social and environmental responsibility of manufacturing

\footnotetext{
* Corresponding author: ela68@mail.ru
} 
enterprises. Energy restrictions and the deteriorating environmental situation inevitably turn information technology into a direction called Green IT (Tab.1).

Green technologies ("Green IT") in the production of computers is an innovation that pays tribute to the requirements of environmental friendliness of production. The purpose of such technologies is to reduce the harmful effects on nature and humans, to take care of future generations both in terms of environmental protection (energy conservation, air pollution, recycling), and to reduce the impact on the health of humans and their offspring.

The agiotage that has arisen in recent decades around environmental problems and related issues of producer responsibility encourages a clear identification and search for solutions to numerous problems caused by the development of information technologies and the expansion of the production of computers and components. The complex of problems that arise at the intersection of Economics, ecology and ethics involves the active introduction and implementation in practice of ethical principles of responsible attitude to nature, care for future generations, respect and observance of the rights of all living things.In the last 2-3 years, the topic of environmental responsibility of computer technology manufacturers has been one of the most frequently discussed topics in the media, scientific and business conferences, and exhibitions.

Table 1 - Benefits of Green IT:

\begin{tabular}{|l|l|}
\hline Recycling & $\begin{array}{c}\text { Green technology helps manage and recycle } \\
\text { waste material. It allows it to be used for beneficial } \\
\text { purposes. This technology is used for waste } \\
\text { management, waste incineration, and more. A lot of } \\
\text { recyclable material has allowed individuals to create } \\
\text { plant fertilizer, sculptures, fuel, and even furniture. }\end{array}$ \\
\hline Purifying of Water & $\begin{array}{l}\text { Green technology purifies water. The } \\
\text { scarcity of pure drinking water is a major concern. } \\
\text { Through the use of various technologies a lot of } \\
\text { campaigns have been successful in providing people } \\
\text { with clean drinking water. }\end{array}$ \\
\hline Purifying the Air & $\begin{array}{l}\text { Dealing with carbon emission is another } \\
\text { focus. While the human race is improving in terms of } \\
\text { various technologies. The automobiles, factories, etc. } \\
\text { are emitting a lot of carbon that is detrimental to the } \\
\text { planet. Green technology helps to reduce carbon } \\
\text { emission and purify the air. This allows people and } \\
\text { other living things to breathe properly. }\end{array}$ \\
\hline Conserving Energy & $\begin{array}{l}\text { Energy is being conserved through the use } \\
\text { of such technology. Alternatives to devices that use a } \\
\text { lot of electricity or fuel are being introduced to the } \\
\text { public. The use of electric cars is on the rise, } \\
\text { especially in the UK. People using environment } \\
\text { friendly devices and appliances is encouraged. While } \\
\text { installation of such devices, namely solar panels, } \\
\text { might be expensive for some people the benefits it } \\
\text { offers with regards to reducing bill expenses are } \\
\text { tremendous. }\end{array}$ \\
\hline
\end{tabular}

\section{Literature review}

The ability to cope with the complexity of modern socio-economic problems depends crucially on the availability of an effective communication network. Like the neural network of the biological brain, this network determines the learning ability that helps humanity survive. In accordance with the theory of complex networks, attempts are made to model the dynamics of information technologies spreading in the economic and cultural 
environment. This is how the concept of information and computing ecology was born. Examples of such systems already exist in reality - ticket reservation systems, banking systems, and research laboratories, which include networks with numerous computers of various types.[1-3]

Kupalova, G. and Goncharenko, N. (2020) wrote that,implementation of the principles of sustainable development, ecologization of the economy, environmental modernization of production and reduction of anthropogenic impact on the environment largely depend on the provision of qualified, economically and environmentally competent, conscious management personnel.[4] To train these professionals, it is necessary to introduce in the educational process innovative methods and information systems, primarily, in teaching disciplines of interdisciplinary environmental and economics profile (ecological management, environmental entrepreneurship, modern green business technologies, strategy of green development enterprise, ecological economy, ecological accounting etc.).[5-6]

It is interesting that active discussion of global ecology issues in the scientific world began only in the twentieth century, despite the fact that people from the earliest stage of their existence changed the world around them.[7] People rarely think about the fact that using the fruits of technology, they, in fact, consume resources. Creating a variety of devices, products, services, and new technologies requires natural resources.Technological processes that bring more and more benefits and convenience to humanity are usually direct (or indirect) sources of environmental pollution.[8]As we can see, the rapid human activity on the development of natural resources, overpopulation, atmospheric pollution, destruction of the earth's flora and fauna promises little good and is already causing a large number of disasters.[9]

Humanity does not stop increasing the production of material goods, and growing cheap production is very bad for the environment-polluting rivers, poisoning the air, and sometimes leads to more serious consequences in the form of environmental problems.[10]But it's not just industry that pollutes the environment.Anti-pollution experts have measured the harmful effects of Google search on mother nature. On average, one Google search results in the emission of 7 grams of carbon dioxide into the atmosphere, which corresponds to half of the $\mathrm{CO} 2$ emission from boiling water in a kettle. [11]

According to the Harvard physicist Alex Gross, who studies the impact of the computer industry on the environment. In addition, according to the scientist: "the Search algorithm is optimized for fast results, not for energy savings." Given that Google processes more than 200 million requests per day, these grams add up to a fairly impressive mass of carbon dioxide, which contributes to global warming. [12] Of course, Google is not the only culprit: all IT companies are working to destroy the ozone layer, according to experts. Back in the middle of last year, experts recorded a" victory " of computers, whose total harmful impact on the environment was greater than that of all airlines combined.[13]Experts from the British computer society also warn of the dangers posed by the craze for social services like Twitter. Users of the resource generate millions of messages every month, which requires a huge amount of energy.

In the article ,Mutanov G. and Sayabek Ziyadin(2019) said, that Eco-innovation describes the creation of novel and competitively priced goods, processes, systems, services, policies, and procedures that satisfy human needs and improve the quality of life 
while ensuring sustainable development with minimal use of natural resources and minimal release of toxic substances.[14]

Even the Internet can, though indirectly, influence the ecology of the world. For example, more than 30 billion VVT/h is spent per year on sending ads on the Internet, which leads to the release of more than 17 billion tons of carbon dioxide into the atmosphere. In fact, that modern information technologies are ahead of aviation in terms of carbon dioxide emissions. And accordingly, with the development of information transfer technologies, the amount of $\mathrm{CO} 2$ in the atmosphere will increase.[15]

The use of computer technology in various fields of human activity and the avalanche increase in information are characteristic features of the scientific and technical revolution. [16]Computer technology made it possible to organize various information into banks and databases. The development of any database includes the definition and justification of the subject area.Software is a generic term used to describe instructions at all levels for managing the hardware of computers. [17]Different levels of software have the appearance of a pyramid. The basis of the pyramid, which is closest to the computer hardware, is machine languages. The middle level is formed by languages designed to create applications that convert human-defined instructions into machine codes. The top of the pyramid closest to the user is apps.[18]

Applications are a set of user interface tools that the user uses to perform the actions necessary to complete a task. The user interface is a means of interaction between the user and the application.[19-20]

\section{Methodology}

Currently, the rapid development of computer technology, the introduction of modern computer technologies opens up wide opportunities to achieve a qualitative leap in the level of efficiency of information and control systems in aerospace engineering, manufacturing, transport, economy, ecology, medicine and other areas based on the use of artificial intelligence principles, methods of self-organization and adaptation to changing conditions and goals of functioning, characteristics of the system and the external environment, uncontrolled environment. A computer, like any electrical device, is a source of electromagnetic radiation. Accordingly, both the system unit and the monitor emit radiation. According to the degree of radiation hazard, a computer is one of the most dangerous devices, along with microwave ovens, televisions (on CRT), and refrigerators.

By EDI technology which helps us to safe forests. there is no need of usage papers. Electronic data interchange ('EDI) is the concept of businesses electronically communicating information that was traditionally communicated on paper, such as purchase orders and invoices. Technical standards for EDI exist to facilitate parties transacting such instruments without having to make special arrangements.

According to Global Change Biology,almost half of the forests that once covered the Land have disappeared. In just 15 years, from 2000 to 2015, at least 200 million hectares of forest were lost, which exceeds the area of Mexico. Forests once occupied more than half of the land area, and now cover 51.2 million $\mathrm{km} 2$ (37\%). Both the qualitative composition of forests and the productivity of forest stands have deteriorated. Wood stocks of the most valuable species have been significantly depleted, and thousands of species of animals and 
plants have disappeared or are under threat of extinction due to the destruction of forests and changes in their structure. Forests are reduced for three main reasons: development of new territories for agricultural crops and pastures; obtaining wood for construction, woodworking and paper industries; obtaining fuel for cooking and heating. The state of forests on Earth is also affected by: infestation of exotic tree species, outbreaks of insect pests, forest fires, environmental pollution, climate change, as well as mining, construction, and recreational activities

The results of a study by Swedish scientists are widely known. they found that the monitor case, when heated up to 50-55 degrees Celsius during normal operation, begins to emit triphenylphosphate(chemical compound) vapors into the air. But not only the monitor is heated, but also the power supply, and the processor, and then the motherboard, and the video card. And all of them contain various resins, fluorine, chlorine, phosphoruscontaining organic and inorganic compounds that can be released into the air when heated.The monitor body is made of plastic, it takes about $20 \%$. Plastic occupies one of the leading positions in the industry. Once in nature, plastic decomposes for an incredibly long time from 50 to 100 years.

As for the boards, $3 \%$ of all technological garbage that accumulates over the year is allocated to these same boards, and the share of all techno-garbage is about 30 to $50 \mathrm{mln}$, agree, the amount is not small. As computers, televisions, mobile phones, and other electronic devices become more and more accessible in the world, e-waste has been a growing problem in recent years. For example, in 2015 alone, people threw away almost 80 million tons of e-waste.Recycling old CRT monitors is a time-consuming process that will be popular over the next decade, and then, who knows, they may invent monitors that do not need to be disposed of. But until this happens, you should not just throw out old monitors on the street, it is better to spend a little time and take them to recycling, because this way you help keep our world cleaner [21,22,23].

\section{Results and discussion}

These days,companies strive to be socially responsible employers and pay special attention to the issue of environmental friendliness of the services provided, the formation and development of environmental thinking, the ability to apply it in cognitive, communicative, social practice and professional orientation. Moreover, this is one of the priorities of companies in the global strategy.

In addition to creating their own sources of clean electricity, well-known IT corporations (Apple, Microsoft, etc.) will also actively buy it from the owners of wind farms (wind farms), hydro - and geothermal power plants in the medium term, depending on the availability of energy resources.

It is worth noting that many other large IT corporations also invest a lot of money in RES in one way or another. For example, the search giant Google actively invests in such power plants and promising "green" startups, while eBay independently builds 
environmentally friendly generating facilities (solar power plants and fuel cell-based power units) near its data centers.

For example, in Italy, a robot was created whose main task is to clean up garbage and monitor the cleanliness of the air. A group of European scientists have developed and introduced the world to the Dustbot device, a wheeled garbage robot that is supposed to patrol city streets, collect garbage and monitor air pollution. The successful implementation of Dustbot in the garbage collection infrastructure of large cities, especially in Europe, where there are a lot of narrow streets, will allow city authorities to at least partially abandon the use of standard garbage trucks, which, due to their size, create difficulties on city roads and pollute the environment with harmful emissions. Wall-E.

Table 2- Advantages and disadvantages

\begin{tabular}{|c|c|c|}
\hline Source & Advantages & Disadvantages \\
\hline Wind & $\begin{array}{ll}\text { - } & \text { Renewable energy source } \\
\text { - } & \text { Very low greenhouse gas } \\
\text { - } & \text { emissions } \\
\text { - } & \text { Very low air pollution emissions } \\
\text { - } & \text { Very safe for workers and public }\end{array}$ & $\begin{array}{l}\text { - } \quad \text { Intermittent energy source } \\
\text { - } \quad \text { Limited to windy areas } \\
\text { - } \quad \text { Potentially high hazard to birds } \\
\text { - } \quad \text { Moderate land requirements }\end{array}$ \\
\hline $\begin{array}{l}\text { Small } \\
\text { Hydro }\end{array}$ & $\begin{array}{ll}\text { - } & \text { Renewable (if silt removed in } \\
& \text { reservoir) } \\
\text { - } & \text { Rery low greenhouse gas } \\
& \text { emissions } \\
\text { - } & \text { Very low air pollution emissions } \\
\text { - } & \text { Inexpensive to build and operate } \\
\text { - } & \text { Safe for workers and public }\end{array}$ & $\begin{array}{l}\text { - Dependent on stream flow } \\
\text { Large numbers of small dams can } \\
\text { have significant effects on terrestrial } \\
\text { and aquatic habitats, possibly as great } \\
\text { as a large dam producing the same } \\
\text { amount of electricity }\end{array}$ \\
\hline $\begin{array}{l}\text { Large } \\
\text { Hydro }\end{array}$ & $\begin{array}{l}\text { - } \quad \text { Very high return on energy } \\
\text { investment } \\
\text { - } \quad \text { Very low greenhouse gas } \\
\text { emissions } \\
\text { - } \quad \text { Very low air pollution emissions } \\
\text { - Inexpensive once dam is built } \\
\text { - } \quad \text { Can produce energy on-demand } \\
\text { - } \quad \begin{array}{l}\text { Provide water storage and flood- } \\
\text { control }\end{array}\end{array}$ & $\begin{array}{l}\text { - Non-renewable (silt removal } \\
\text { unfeasible) } \\
\text { - Very high land requirements } \\
\text { - Extremely high impacts to land and } \\
\text { water habitat } \\
\text { Best sites are already developed or } \\
\text { off-limits } \\
\text { Disastrous impacts in case of dam } \\
\text { failure }\end{array}$ \\
\hline
\end{tabular}

The project "Synthetic tree." Scientists from the United States are developing an unusual project of a "synthetic tree" that can absorb 1000 times more carbon dioxide than ordinary trees. The tree has plastic "leaves" that capture CO2 molecules when the wind blows. In the future, the absorbed $\mathrm{CO} 2$ is compressed, cooled, and stored in liquefied form. 
At the heart of the work of "synthetic wood" are methods of capturing gases, similar to those that are now used in some chemical industries, as well as at stations for burning coal.

Method of plastic decomposition. Our planet is overgrown with plastic garbage at a cosmic speed. You can't burn it, because it creates toxic compounds, but simply burying it in the ground is useless: the same plastic bag can lie there untouched for more than a century. Scientists have long been looking for an accelerated and harmless way to dispose of used plastic products. As a result, plastic was invented that can rot in just a couple of years. To do this, so-called additives were added to its composition. According to scientists, these substances that act on polymer materials, like a bug-tree beetle on old furniture, decompose them into components that are harmless to the environment and to humans.

Hyundai environmental technologies. The issue of producing "green" cars is becoming more relevant every year. Hyundai plans to become a major player in the global market for the production of such cars. Hyundai invests heavily in the development of an eco-friendly and economical car. More than a decade of experience in the company's development shows this. This is confirmed by the latest premieres of Hyundai concept cars at various international motor shows. The development of environmentally friendly vehicles with a low emission of toxic exhaust gases will: reduce the amount of petroleum products used and reduce $\mathrm{CO} 2$ emissions. Hyundai Getz is one of the first such cars.

Pavement. Dutch researchers from the University of Twente have developed a road surface material that can purify the air from car exhausts, according to The Engineer. In the near future, this material will cover the pavement in one of the cities of the Netherlands for comparative tests. The new material is concrete with additives of titanium dioxide, which is a photocatalyst that can turn toxic nitrogen oxides from car exhausts into harmless nitrates. Nitrogen oxides are a major component of urban smog, and they are eventually converted to nitric acid.

Following the environmental principle of "Think globally, act locally", many companies create a common large-scale space to attract public attention to specific projects and actions. In addition, IT companies are buying up so-called "green" certificates to compensate for their carbon footprint, so we can note that there are already positive changes in this direction.

Table 3- SWOT analysis:

\begin{tabular}{|l|l|}
\hline $\begin{array}{l}\text { Strength } \\
\text { The development of the ecovillage } \\
\text { Organic solar panels } \\
\text { Biofuel }\end{array}$ & $\begin{array}{l}\text { Weaknesses } \\
\text { Noise, vibration, electromagnetic fields } \\
\text {,pesticides and nitrates , large factories which } \\
\text { pollute the environment }\end{array}$ \\
\hline $\begin{array}{l}\text { Opportunities } \\
\text { Internet access } \\
\text { Can produce energy }\end{array}$ & $\begin{array}{l}\text { Threats } \\
\text { Harm to environment } \\
\text { Chemical compounds }\end{array}$ \\
\hline
\end{tabular}

\section{Strength:}

Communication systems such as the Internet and cell phones speed up the exchange of all types of information, including environmental data. By connecting people located at a great 
distance, the network helps researchers and activists work together to solve environmental problems. An increasingly extensive communication network transmits information to remote areas where it can be used to support human development - to help teachers expand their training programs, doctors provide information and ambulance services to people, and farmers and rural entrepreneurs enter urban markets for their products.

And another use of information technology benefits the environment - for example, replacing computer data with actual use of materials and energy, or replacing transportation needs with telecommunications. (Tab.3)

\section{Weaknesses:}

The negative side is that computers consume electricity and use paper, while radio, television, and the Internet transmit ads and programs that can encourage people to buy resource-intensive products.

Computers, satellites, televisions, and other telecommunications equipment significantly burden The earth's resources during their lifetime. Computer manufacturing requires energy and water, and creates waste, many of which are dangerous. In the production of semiconductors, printed circuit boards and cathode-ray tubes for computer monitors and television screens, toxic solutions, acids and heavy metals are used. for example, in the production of a 25-kilogram computer, $63 \mathrm{~kg}$ of waste is created, $22 \mathrm{~kg}$ of which are toxic.

Computers and mobile phones represent a huge problem of their utilization is partially due to the fact that they are quite old. Based on this, the repair is quite expensive compared to the cost of a new product. When computers are discarded as junk, the lead in the monitors, mercury and chromium in the main processor unit, and arsenic and halogen organic substances inside the devices all pose a health hazard.

Recycling computers and phones is complicated by the fact that the design of most of them does not provide such a possibility, so recycling computers is economically unprofitable. It is particularly difficult to recycle small electronic devices such as mobile phones.

\section{Opportunities:}

There are a large number of plug-in JavaScript libraries. The popular jQuery library focuses on the interaction of JavaScript, HTML, and CSS. It allows you to access and manipulate any element of the DOM (document object model); work with events; easily implement various visual effects; work with AJAX (a technology that allows you to communicate with the server without reloading the page); has a huge number of JavaScript plugins designed to create user interface elements.

\section{Threats:}

Improper disposal of computers causes significant harm to the environment. To eliminate (or reduce) harmful effects, it is necessary to properly dispose of used equipment.

In the manufacture of computer parts, toxic substances (arsenic, mercury, lead, and others) are used, which, if improperly disposed of, poison the environment and pose a danger to human life, and this is reflected in the work [23, 24]

\section{Conclusion}


It is also necessary to take into account that the impact of information technologies on people and the environment is bi-directional. On the one hand, information technology is one of the most promising tools for data collection and scientific knowledge, including in medicine and ecology. On the other hand, it is an important factor that affects human health and the environment.

Information technologies are actively used both for direct impact and for providing feedback. And the existence of the system is possible only if both links are present and functioning correctly. The timeliness and accuracy of the received information and control signals is very important. In this area, many functions should be assigned to information technology and computer technology.

Information technologies are becoming more widespread in the fields of medicine and ecology. At the moment, the General principles and structures of global information systems that solve problems of human health and the environment have been developed. However, the potential in this area far exceeds our capabilities.

The most important and most significant changes in human society are changes in people's minds. These changes will allow us to create really new technologies.Information technologies not only shape our worldview, but also enhance our ability to change the world. We are responsible for using these funds to build a healthy and fair future.

The harmful influence of man on the global environment is obvious. A world without plants, birds, crystal rivers, blue skies, and clean air can't be home to a person.

\section{References}

1. V. A. Babichenko, O. M. Babchenko, M. V. Zaretskaya, The integration of software and algorithmic tools for the analysis and prognosis of the state of the environment, (2008)

2. B. N. Bessonov, N. P. Vashchekin, A. D. Ursul. Methodology of science and strategy for the survival of civilization, (1999)

3. S. M. Kovalenko, O. V. Platonova, Analysis of the problem of effective operation of automation systems complexes and reliability calculations based on continuous models. News of higher educational institutions. Mechanical engineering, 8 (653) (2014)

4. V. F. Krapivin, Information systems for environmental monitoring Problems of the environment and natural resources.(2010)

5. A. A. Kuzmin, Organization of ensuring the safety of a dangerous production facility based on a quantitative assessment of the state of its security system. Civil security technologies, 8(4) (2011)

6. D. A. Kuzmina, Problems of the environment and natural resources: Overview, (9) 7 (2003)

7. V. Levin, Internet-UN-t inform. technologies', (2007)

8. V. D. Parajanov, Sustainable development and problems of improving intelligence (2019) 
9. G. Riznichenko, Mathematical modeling of biological processes. Litres, (2013)

10. I. A. Matyushenko, I. V. Shulgin, Scientific and methodological electronic journal Concept, (13) 1921-1925 (2015)

11. F. I. Sharkov, V. V. Silkin, I. E. Abramova, N. V. Kirillina, Violation of information ecology in media space.(2020)

12. RUDN Journal of Sociology, 18 (4) 765-775 (2018)

13. Y.C. Fung, Biodinamics (Circulation). New York: Springer-Verlag, 404 (1984)

14. G. Mutanov, S. Ziyadin, A. A. Shaikh. Graphic model for evaluating the competitiveness and eco-efficiency of eco-innovative projects, 4 (6) (Enterpreneurship and Sustainability Issues 2019)

15. A. V. Kopyltsov , Russian Journal of Numerical Analysis and Mathematical Modeling, 26 (6) 535-553 (2012)

16. Y. C. Fung Biomechanics (Mechanical properties of living tissues). (New York: Springer-Verlag 1981)

17. A. Grachev, V. Orlov, Information technologies in ecology and nature management. ( Litres 2017)

18. G. V. Vypkhanova, Law and state: theory and practice. 1(122-126), (2008)

19. S. C. Goslee , Journal of Statistical Software. 22 (7) 1-19 (2007)

20. B. N. Bessonov, N. P. Vashchekin, A. D. Ursul, Methodology of science and strategy of civilization survival, (1999).

21.Ziyadin, S., Streltsova, E., Borodin, A., Kiseleva, N., Yakovenko, I., \& Baimukhanbetova, E. Sustainability, 11(9), 2544. (2019). DOI: 10.3390/su11092544

22. Akhmetshin, E. M., Makulov, S. I., Talysheva, I. A., Fedorova, S. Y., \& Gubarkov, S. Man in India, 97(15), 281-288. (2017).

23. Mutanov, G., Ziyadin, S. /E3S Web of Conferences, DOI: $10.1051 / \mathrm{e} 3$ sconf/201913504056 (2019)

24. Koziuk, V., Hayda, Y., Dluhopolskyi, O., \& Klapkiv, Y. Economics \& Sociology, 12(4), 278-333. (2019) 